\title{
EFFECT OF ENDOMETRIAL INJECTION SCRATCHING IN CYCLES OF TREATMENT BY ASSISTED REPRODUCTIVE TECHNOLOGY METHODS
}

\section{INTRODUCTION}

The proportion of patients with repeated failed in vitro fertilization attempts is approximately $30 \%$ of all patients treated using these techniques. Existing literature data on the complex of mechanisms through which maternal-fetal dialogue is integrated indicate that it is the inadequate endometrial receptivity that is responsible for a greater proportion of implantation failures compared to the embryonic factor $[3,11,19]$.

Along with achieving some success in modifying assessment methods and improving embryo quality, there are currently no standardized approaches to determine the optimal endometrium receptivity period for embryo transfer into the uterine cavity. The mechanisms of impaired fertility at the stage of the so-called "implantation window", providing adequate degree of vascularization and angiogenesis processes, which are closely related to the synchronization of morphological, hormonal, cytokine and immunological regulation, remain unjustified. Also, there is no consensus on the regimens of hormonal correction, the duration of its use, and the impact on endometrial functional status and readiness for implantation; no prognostic criteria for pregnancy in patients with unsuccessful attempts at treatment with assisted reproductive technology (ART) have been developed. That is why the task of finding new methods for improving endometrial receptivity and developing complex approaches to medication correction of the processes of regeneration and reception, as well as individualized preparation of a woman's body for implantation, remains relevant $[2,4,5,9,10]$.

Insufficient development of the endometrium in the course of treatment by the methods of ATR may result from the transferred inflammatory diseases of the pelvic organs, changes in hormonal homeostasis, medical manipulations and operations and the associated trauma of the basal layer of the endometrium. One of the most important causes of the decreased reproductive function is impaired intercellular interactions, sclerosis of the stroma around vessels, changes in tissue angioarchitectonics and ischemia $[5,6$, 12]. In the conditions of constant presence of the damaging agent in the tissue, the final phase of inflammation (regeneration) does not end, there is a violation of tissue homeostasis and a whole cascade of secondary lesions is formed. Impaired microcirculation in the endometrium leads to tissue ischemia and hypoxia. Prolonged and often asymptomatic ischemia and tissue hypoxia in the endometrium lead to marked changes in the tissue structure, interfering with normal implantation and placentation, forming a pathological response to pregnancy, and causing impaired proliferation and normal cyclic transformation of the endometrium. As a consequence, hypoplastic processes of the endometrium appear as a biological process that brings together all the links of neurohumoral regulation (genetic and immunological), the role of which has not been sufficiently studied $[2,7,8,10]$. Disorders in the receptive apparatus can lead to insufficiency of the endometrium to exogenous hormonal effects and cases of gestagen resistance.

Optimization and acceleration of the tissue regeneration process is one of the urgent tasks of modern medicine. In the 80th of the XX century, the focus during the stimulation of regeneration processes was on tissue oxygenation [1, 24]. Currently, the main goal of the regeneration processes researches is the identification of growth factors, the disclosure of the action mechanism, and opportunities to use them to accelerate wound healing [13-18]. The transition from one era to another was the discovery of the fact that the influence of oxygen on the macrophages in general and the partial pressure of oxygen in particular, are realized indirectly through angiogenesis factors and other growth factors that promote healing and resist infection.

Platelet-containing autoplasma is non-toxic and non-immunoreactive, it accelerates the natural mechanisms of regeneration due to the presence in platelets of growth factors that drive the natural mechanisms of regeneration. Besides, platelet-containing autoplasma modulates and regulates the function of such primary growth factors as platelet (PDGF), transforming growth factor $\beta$ (TGF- $\beta$ ) family and vascular endothelial growth factor (VEGF). The aforementioned property distinguishes the growth factors of platelet-rich autoplasma from recombinant growth factors, each of which is responsible for a separate mechanism of regeneration [20,23, 25].

Platelets contain the following growth factors: IGF - insulin-like; PDGF - platelet; EGF - epidermal; FGF - fibroblastic; TGF- $\beta$ - "family" of transforming growth factor; PDEGF - platelet growth
L.V. SUSLIKOVA

MD, professor,

director of the Ukrainian State Institute of Reproductology, P.L. Shupik NMAPE, Kyiv ORCID: 0000-0002-3039-6494

V.V. KAMINSKYI

$M D$, professor, corresponding member of the NAMS of Ukraine, head of the Obstetrics, Gynecology and Reproductology Department, P.L. Shupyk NMAPE, head of KCCRPM, Kyiv ORCID: 0000-0002-5369-5817

K.V. CHAYKA

MD, professor, Obstetrics, Gynecology and Reproductology Department, P.L. Shupik NMAPE, Kyiv ORCID: 0000-0003-1738-8796

A.V. KAMINSKYI MD, associate professor, head of Clinic of reproductive technology, USIR, P.L. Shupik NMAPE, Kyiv ORCID: 0000-0002-4341-249X

A.V. SERBENIUK PhD, obstetrician-gynecologist, Clinic of reproductive technology, USIR, P.L. Shupik NMAPE, Kyiv ORCID: 0000-0002-7212-2678

R.V. ZHYKHARSKYI PhD, head of the Department of Endometriosis and Pelvic Surgery, KCCRPM, Kyiv

ORCID: 0000-0003-1146-5113

O.Y. BONDARUK

graduate student, Obstetrics, Gynecology and Reproductology Department, obstetrician gynecologist, Clinics of Reproductive

Technologies, USIR, P.L. Shupyk NMAPE, Kyiv

ORCID: 0000-0001-6472-8744

Contacts:

Lidiia V. Suslikova Ukrainian State Institute of Reproductology, P.L. Shupik NMAPE Geroiv Stalingrada Ave., 16 04210, Kyiv, Ukraine

Tel.: +38 (044) 4119233 email:kagir@ukr.net 
factor of endothelial cells; VEGF or PDAF - vascular endothelial growth factor; PLGF-1 and PLGF-2 - placental growth factors, as well as thrombospondin, osteonectin, "culture shock protein". Growth factors are delivered to tissues in autoplasma injections and stimulate fibroblast formation. Fibroblasts, in turn, produce collagen, hyaluronic acid and elastin. This process leads to the formation of young connective tissue, the growth of capillaries. The result is the restoration of metabolic processes, improvement of microcirculation and metabolism in tissue cells, normalization of tissue respiration, and activation of local immunity. By launching all the links of natural regeneration processes simultaneously and acting synergistically, autoplasma containing platelets is a convenient and safe biological "tool" for accelerating regenerative processes. Autoplasma itself is natural for the human own tissues, accessible in the biochemical ratio of components that is inherent in a given organism $[21,22,26]$.

Objective of the study: optimization of infertility treatment tactics in patients with tubal-peritoneal infertility factor and marked delay in endometrial development after unsuccessful attempts of ART treatment by the use of endometrium injection scratching technology with autoplasma.

\section{MATERIALS AND METHODS}

The study was conducted at the Clinic of Reproductive Technologies of the Ukrainian State Institute of Reproductology, P.L. Shupyk National Medical Academy of Postgraduate Education, and Reproductology and Endocrine Gynecology Department of the Kyiv City Center for Reproductology and Perinatal Medicine. The prevalence of delayed development of the endometrium in the middle and late proliferation phase during controlled stimulation of superovulation in the treatment cycle by the ART techniques was investigated and the features of clinical and anamnesis data in patients with pronounced endometrial development were studied.

40 patients with unsuccessful attempts of treatment by the ART methods and delayed development of the endometrium with tubal peritoneal factor infertility took part in the study. To identify the delay of endometrial development, ultrasound (thickness and macrostructure), Doppler (blood flow in uterine vessels), cytological and histological criteria were established. The presence of endometrial pinopods was detected by performing selective electron microscopy. The study of endometrial pinopods was performed in 40 women with severe endometrial retardation and unsuccessful treatment attempts in the ART program. They underwent pipelle biopsy with endometrial sampling for histological examination and scanning electron microscopy, and immunohistochemical study of C138 marker to exclude chronic endometritis on L7 (21 day of the menstrual cycle $(M C)$ ). The studies were performed before and after the correction of severe endometrial growth retardation with the help of the own developed method, followed by embryo transfer of vitrified embryos (cryo-ET) program.

Patients with severe delay of endometrial development who underwent the ART treatment were divided into groups: I group consist 21 patients who underwent endometrial injection scratching and hormone replacement therapy (HRT) with a standard $(4 / 6 \mathrm{mg})$ dose of estradiol; II group - 19 patients who were prescribed HRT with a standard $(4 / 6 \mathrm{mg})$ dose of estradiol. Control group consist of 10 patients with normal endometrium who underwent cryo-ET with standard $(4 / 6 \mathrm{mg})$ dose of estradiol. The average age was $39.5 \pm 3.1$ years.

Criteria for selecting patients for study:

1) reproductive age from 20 to 40 years; ovulation (normogonadotropic); absence or complete obstruction of the existing fallopian tubes;

2) absence of endometriosis, hyperprolactinemia, diabetes and other endocrine disorders;

3) no pathology of the uterine body (fibroids with deformity of the uterine cavity, adenomyosis of II-III degree according to ultrasound, congenital abnormalities of development);

4) normospermia in a man.

In the embryological protocol: embryos of satisfactory quality, the number of embryos - two or more, which allowed a more objective assessment of the clinical significance of the endometrial factor of infertility.

Sonoscopy and Doppler assessment of blood flow in the pelvic organs was performed on the 7th, 14th and 21st day of MC. Patients in the ART cycle were monitored for follicular growth and evaluation of the structure and thickness of the endometrium. To measure blood flow in the uterine vessels, color Doppler mapping was performed using a transvaginal ultrasound scanner TOSHIBA APLIO MX (Japan) with a three-dimensional imaging function and a directional Doppler trans-abdominal and transvaginal convex sensors with frequency 4.0-7.0 and 5.6-8.0 MHz, respectively. Changes in the quantitative indices of blood flow in uterine, arcuate and radial arteries were analyzed, the indices of angle-independent Doppler metric indices of resistance (systolic-diastolic ratio $(S / D)$, resistance index (RI) and pulsation index (PI)) of uterine vessels: uterine (Ua), arcuate ( $\mathrm{Aa}$ ) and radial ( $\mathrm{Ra}$ ) arteries were evaluated.

Sampling of the microbioptate from the uterine cavity for cytological examination was performed using uterobrash on the 7th day of the stimulation cycle and on the day of the transvaginal oocyte retrieval in the treatment program by the ART methods, on the 7th day of pre-gravid preparation during hormone replacement therapy, and on the day of progesterone prescription before cryo-ET. Cytological examination was conducted by the polychrome method according to Papanicolaou and Pappenheim monochrome method.

Injection scratching technique: office hysteroscopy was performed using a Hopkins II rigid hysteroscope made by KARL STORZ (Germany) with a $2.0 \mathrm{~mm}$ outer diameter of the distal part, with $4.2 \mathrm{~mm}$ diameter of an operating tube for constant irrigation forming. Through the hysteroscope operating channel, a needle was introduced into the uterine cavity with a triple sharpening of the tip of the pencil type $0.53 \mathrm{~mm}$ in diameter, and microinjections of plasma, enriched with platelets, and scratching of the basal layer of the endometrium from the inner uterus to the bottom of the uterus and along the uterus were performed along the uterus from one proximal ostium of the uterine tube to the other. Obtaining autoplasma involved the separation and concentration of platelets. For this purpose, a system for platelets concentration SMART Prep2 was used. By two-step centrifugation, first erythrocytes and leukocytes (platelets remained in the supernatant) were removed from 40 
$\mathrm{ml}$ of whole peripheral blood of the patient, and then, at the second centrifugation, the platelets were concentrated. Platelet-enriched plasma was prepared ex tempore, immediately prior to surgery.

In the analysis of the collected actual material in determining the rate of pregnancy, only clinically confirmed pregnancy was considered (ultrasound detection of a fetal egg on the 28th day after embryo transfer). Accordingly, the early (first trimester) reproductive loss rate was calculated solely from the number of reported clinical pregnancies.

Statistical processing of the research results was performed using Statistica 6.0 software package and Microsoft Office software package using standard descriptive statistics methods.

\section{RESULTS}

Histological examination of endometrial samples from 40 women with severe endometrial growth retardation and unsuccessful attempts at treatment in the ART program revealed that in 17 (42.50\%) patients the endometrium according to O.I. Topchiyeva and R.W. Noyes criteria did not correspond to the phase and day of $\mathrm{MC}$, and was in the phase of proliferation or early secretion. In 23 women (57.50\%) whose endometrium, according to the above criteria, met the middle secretory phase and $L+7$ day $M C$, chronic endometritis was not registered (the presence of chronic endometritis was a criterion for exclusion from the study). Comparative analysis of the endometrial morphofunctional state in women with severe endometrial developmental delay and unsuccessful attempts at treatment in the ART program and the control group it was found that the probable features of the endometrium in infertile women were the areas of pinopods absence in $47.50 \%$ of cases, small size of pinopods - in $77.50 \%(p<0.01)$ and abundant microvilli in $37.50 \%(p<0.02)$; reduced frequency of developed pinopods presence by 2.12 times ( $p<0.01$ ), pinopods of large sizes - by $2.29(p<0.01)$ and small number of microvilli - by 4.00 ( $p<0.0001)$, increased incidence of medium size pinopods in $3.00(p<0.02)$ times, microvilli in moderation $-4.00(p<0.0001)$ (Table). A characteristic feature of endometrial pinopods in patients with tubal-peritoneal infertility was mosaicism of their shape $(65.00 \%)$ and size $(67.50 \%)$.

In patients of the control group on $\mathrm{L}+7$ day microvilli were practically absent and the maximum protrusion of epithelial membranes was observed; therefore, pinopods were mainly of the big sizes (Fig. 1). In women with tubal-peritoneal infertility and severe retardation of endometrial development, where the injection endometrial scratching method was used for endometrium, which, according to O.I. Topchiyeva and R.W. Noyes criteria, corresponded to the MC phase and day (Fig. 2), large pinopods were also observed, but in the vast majority of cases they were with abundant microvilli or microvilli in moderation. In $15.00 \%$ of cases, regressing pinopods were observed, represented by reduced and shrunken cells.

Endometrium in women with tubal-peritoneal infertility and severe retardation of endometrial development, when the injection endometrial scratching method was not applied; the endometrium, according to O.I. Topchiyeva and R.W. Noyes criteria did not correspond to the MC phase and day, was in the phase of proliferation or early secretion, there was a delay in the pinopods development. They were small, covered abundantly or moderately with short and thick microvilli (Fig. 3). There were areas of no pinopods.

In the cryo-ET program in patients with marked delay in the development of the endometrium in their traditional (without the use of injection scratching) management (group II, $n=19$ ), the rate of pregnancy onset was $10.3 \%$ (2 from 19), which was almost 4 times less than in patients with normal endometrial thickness (control group, $n=10)-40 \%$ (4 from 10) (Fig. 1). The difference between the compared indicators was significant

Table. Features of pinopods and microvilli in the endometrium of women with tubal-peritoneal infertility, severe endometrial retardation and failed treatment attempts in the ART program on $\mathrm{L}+7$ day, $\mathrm{n}(\mathrm{P} \pm \mathrm{p}, \%)$

\begin{tabular}{|c|c|c|c|c|}
\hline Indicators & Tubal-peritoneal infertility group, $n=40$ & Group I, $n=21$ & Group II, $n=19$ & Control group, $n=10$ \\
\hline \multicolumn{5}{|c|}{ Pinopods } \\
\hline Areas of absence & $19(47,50 \pm 1,10)^{c}$ & $12(57,14 \pm 1,69)^{c}$ & $7(36,84 \pm 1,43)^{c}$ & $0(0,00 \pm 0,00)$ \\
\hline Developing & $32(80,00 \pm 1,43)^{c}$ & $20(95,24 \pm 2,17)^{\mathrm{c}, 1}$ & $12(63,16 \pm 1,87)^{c, 1}$ & $1(10,00 \pm 1,05)$ \\
\hline Developed & $17(42,50 \pm 1,04)^{c}$ & $4(19,05 \pm 0,97)^{c, 1}$ & $13(68,42 \pm 1,94)^{\prime}$ & $9(90,00 \pm 3,15)$ \\
\hline Regressing & $6(15,00 \pm 0,62)$ & $4(19,05 \pm 0,97)$ & $2(10,53 \pm 0,76)$ & $0(0,00 \pm 0,00)$ \\
\hline Small size & $31(77,50 \pm 1,40)^{c}$ & $17(80,95 \pm 2,00)^{c}$ & $14(73,68 \pm 2,02)^{c}$ & $0(0,00 \pm 0,00)$ \\
\hline Medium size & $24(60,00 \pm 1,24)^{c}$ & $15(71,43 \pm 1,88)^{c}$ & $9(47,37 \pm 1,62)$ & $2(20,00 \pm 0,00)$ \\
\hline Large size & $14(35,00 \pm 0,95)^{c}$ & $4(19,05 \pm 0,97)^{c, \| l}$ & $10(52,63 \pm 1,71)^{\prime}$ & $8(80,00 \pm 0,00)$ \\
\hline Different shape & $31(65,00 \pm 1,29)^{c}$ & $14(66,67 \pm 1,82)^{c}$ & $12(63,16 \pm 1,87)^{c}$ & $0(0,00 \pm 0,00)$ \\
\hline Different size & $27(67,50 \pm 1,31)^{c}$ & $14(66,67 \pm 1,82)^{c}$ & $13(68,42 \pm 1,94)^{c}$ & $0(0,00 \pm 0,00)$ \\
\hline \multicolumn{5}{|c|}{ Microvilli } \\
\hline Abundant & $15(37,50 \pm 0,98)^{c}$ & $13(61,90 \pm 1,75)^{c, \|}$ & $2(10,53 \pm 0,76)^{c, 1}$ & $0(0,00 \pm 0,00)$ \\
\hline Moderate number & $16(40,00 \pm 1,01)$ & $5(23,81 \pm 1,09)^{\|}$ & $11(57,89 \pm 1,79)^{c, 1}$ & $1(10,00 \pm 1,05)$ \\
\hline Small number & $9(22,50 \pm 0,76)^{c}$ & $3(14,29 \pm 0,84)^{c}$ & $6(31,58 \pm 1,32)^{c}$ & $9(90,00 \pm 3,15)$ \\
\hline
\end{tabular}

., I,I - difference is statistically significant between the corresponding indicators in control group, group I, group II ( $p<0,05)$; one patient might have areas with pinopods and microvilli of different size, shape and stage of development. 


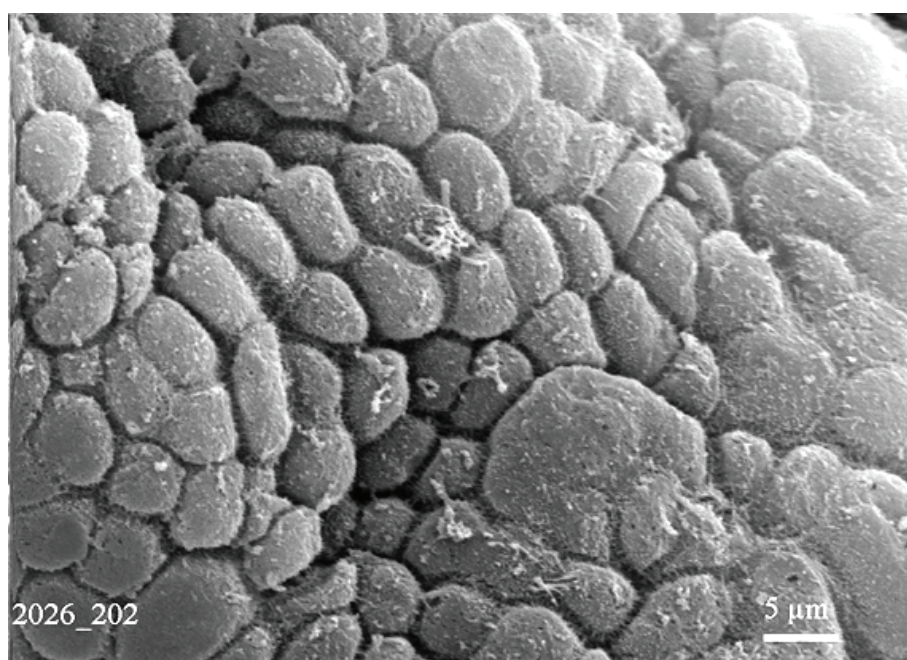

Figure 1. Well-developed pinopods in patients of the control group on L+7 day. Single microvilli

Scanning electron microscopy. Magnification x 2000

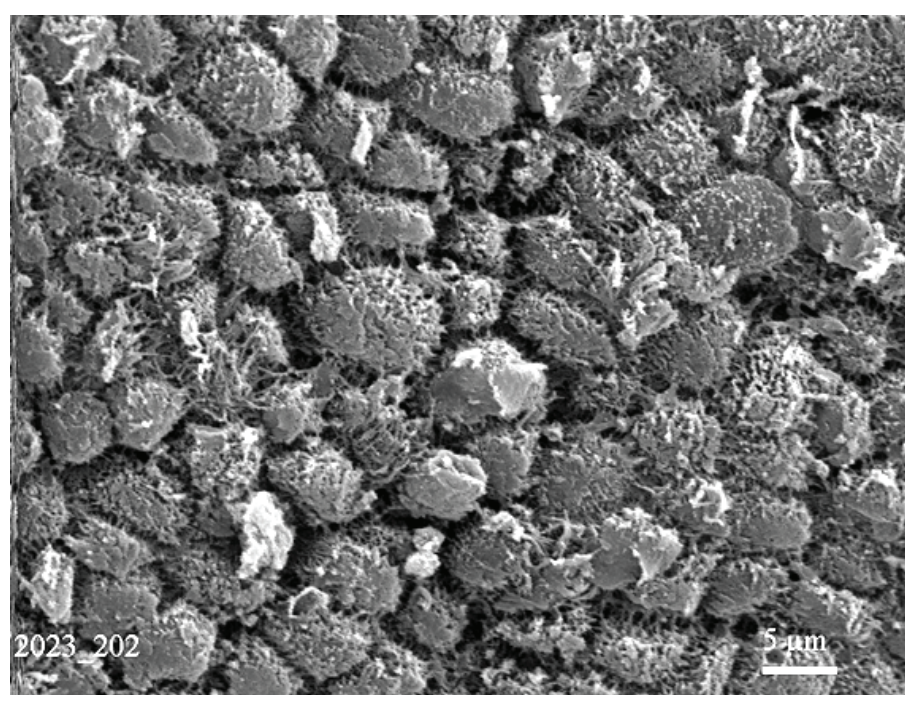

Figure 2. Pinopods of large and medium size, different in shape in patients with tubalperitoneal infertility on $L+7$ day with the correspondence of phase and day of MC. Moderate number of microvilli

Scanning electron microscopy. Magnification x 2000.

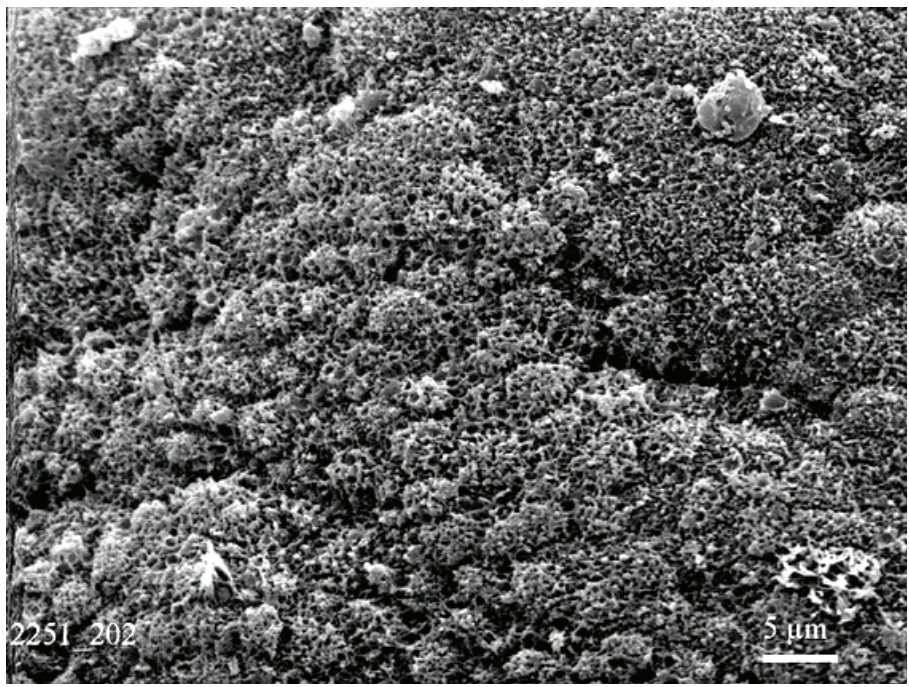

Figure 3. Small, different in shape and size pinopods in patients on $L+7$ day with tubalperitoneal infertility and the mismatch of endometrial phase and MC day Scanning electron microscopy. Magnification x 2000 $(p=0.027)$, indicating that there is a negative impact of a marked delay in the development of the endometrium on the likelihood of successful implantation.

If patients with a sign of marked delay in the endometrium development had injection scratching performed (group $\mathrm{I}, \mathrm{n}=21$ ), then the frequency rate of the onset pregnancy was $23.7 \%$, which was 2 times higher than in patients with the same endometrial condition who received traditional treatment. At the same time, the efficiency of cryo-ET by the analyzed indicator in percentage calculation in this group is still significantly (twice) lower than the results observed in the group of women (control group, $n=10$ ) with normal development of the endometrium. The rate of pregnancy termination in the first trimester in patients of control group $(\mathrm{n}=10)$ was $25 \%$ ( 1 from 4$)$. Four women who became pregnant with marked delay of endometrial development and received traditional treatment (group I) in the pretransfer period, pregnancy ceased to develop in the short term; the rate of early reproductive loss in this group was $100 \%$.

The use of injection scratching in women with marked delay of endometrial development in cases of subsequent successful implantation reduced the rate of early reproductive losses to $25 \%$ (1 from 4) compared with $100 \%$ in the frequency of reproductive losses in cases where injections were not applied. This fact can be regarded as a positive result of the study, because otherwise (if injection scratching was not applied), the likelihood of loss of induced pregnancy was much higher. However, compared with women with normal endometrial development, the frequency of early reproductive losses in patients with severe developmental delay who used pretransfer injection scratching was 1.6 times higher $(22.2 \%$ versus $14.3 \%$ ). This observation indicates that endometrium injection scratching does not provide a complete restoration of the implantation capacity of the endometrium up to normal functioning at early gestation in cases of its marked developmental delay at the stage of preparation with estrogen medication.

When Doppler ultrasound of vessels of the uterus with color Doppler mapping was made after injection scratching procedure, the following changes of uterine perfusion were noted: S/D decreased by $36.5 \%$ at the level of uterine arteries (from $6.82 \pm 1.12$ to $4.33 \pm 0.8, \mathrm{p}<0.05$ ); by $42.6 \%$ in arcuate arteries (from $5.4 \pm 1.4$ to $3.1 \pm 0.7, p<0.01$ ) and by $30.5 \%$ in radial arteries (from $3.6 \pm 1.09$ to $2.5 \pm 0.7, p<0.05$ ).

$\mathrm{PI}$ decreased in uterine arteries by $24 \%$ (from $2.9 \pm 0.2$ to $2.2 \pm$ $0.3, \mathrm{p}<0.05$ ); in arcuate - by $5 \%$ (from $2.0 \pm 0.2$ to $1.9 \pm 0.2$ ) and in radial - by $3 \%$ (from $1.5 \pm 0.5$ to $1.45 \pm 0.6$ ).

$\mathrm{Rl}$ decreased in uterine arteries by $10.9 \%$ (from $0.92 \pm 0.09$ to $0.82 \pm 0.06, p<0.05$ ); in arcuate - by $11.9 \%$ (from $0.84 \pm 0.07$ to $0.74 \pm 0.05, p<0.05$ ) and in radial arteries - by $15.6 \%$ (from $0.77 \pm$ 0.06 to $0.65 \pm 0.04, p<0.05$ ).

Changes in all indices were unidirectional in the downward direction and were significant $(p<0.05, p<0.01)$ compared to reference values. S/D decreased in the uterine arteries by $5.4 \%$ (from $3.13 \pm 0.8$ to $2.96 \pm 0.4, p<0.05$ ); in arcuate by $23.6 \%$ (from $3.05 \pm 0.9$ to $2.33 \pm 0.3$ ) and in radial by $3.6 \%$ (from $2.5 \pm$ 0.8 to $2.41 \pm 0.3$ ) 
There was a decrease in PI in the uterine arteries by $9 \%$ (from $2.4 \pm 0.24$ to $2.2 \pm 0.3$ ), RI by $18.2 \%$ (from $0.88 \pm 0.04$ to $0.72 \pm$ $0,03, \mathrm{p}<0.05)$; in arcuate $\mathrm{PI}$ decreased from reference level by $4 \%$ (from $1.96 \pm 0.3$ to $1.88 \pm 0.6, p<0.01$ ), RI by $11.4 \%$ (from $0.79 \pm 0.05$ to $0.70 \pm 0.03, \mathrm{p}<0.05)$; in radial PI decreased by $21 \%$ from $1.8 \pm 0.02$ to $1.42 \pm 0.04, p<0.01$ ), RI - by $6.8 \%$ (from $0.73 \pm 0.04$ to $0,98 \pm 0.02, p<0.01)$.

The study showed that ultrasound scan and dopplerometry of uterine vessels can be used as an additional method to diagnose the initial hemodynamic disorders and evaluate the effectiveness of correction of the endometrium development in cycles of treatment of tubal-peritoneal infertility by ART.

\section{DISCUSSION}

Analysis of the present-day literature indicates that there are many unresolved issues in the treatment of patients with unsuccessful ART cycles in the past: there are no predicting methods for effectiveness of infertility treatment by ART methods and clear criteria for selection of optimal treatment and rehabilitation measures before the next treatment programs by ART methods, effective treatment and rehabilitation procedures in ART and determination of the optimal time for their implementation.

In women with tubal-peritoneal infertility and severe endometrial retardation and failed treatment attempts in the ART program dysfunction of endometrium receptivity is observed, which is manifested by abnormalities in the development of pinopods and their microvilli during the implantation window. A characteristic feature of endometrial pinopods in women with tubal-peritoneal infertility, severe endometrial retardation and failed treatment attempts in the ART program is a mosaicism of their shape and size.

The ultrasound signs of delayed endometrial development are a recorded decrease in its thickness (up to $4 \mathrm{~mm}$ and less with a pronounced delay) and disruption of the macrostructure (lack of a clear three-layer structure), which was accompanied by changes in blood flow in uterine, arcuate and radial arteries, $\mathrm{Pl}$, decreased $\mathrm{RI}$, which confirmed the decrease in tissue perfusion in uterus.

Increasing the daily dose of estrogen medicine during pregravidar (pre-pregnancy) preparation in the cryo-ET cycles in patients with severe endometrial development delay on day 7 of HRT did not provide an increase in endometrial thickness until the day of human chorionic gonadotropin injection and did not improve clinical outcomes.

In cryo-ET program, the implementation of injection scratching with autoplasma in patients with marked endometrial development delay, after the first seven days of monotherapy with a starting dose of estradiol, was accompanied by a significant improvement in clinical outcomes in terms of pregnancy rate $(23.5 \%)$ and significant decrease of early reproductive losses (25\%).

\section{CONCLUSIONS}

Women with infertility of tubal-peritoneal genesis, combined with marked delay in endometrial development, should be attributed to the risk group of unsuccessful ART attempts and reproductive losses (pregnancy termination in the first trimester). Algorithm for examination of patients with unsuccessful attempts of treatment with ART in the anamnesis should include during pre-gravid preparation not only complex examination in the cycle preceding the treatment cycle, but also examination of histological and immunohistochemical criteria for endometrial development delay and the presence of endometrial pinopods by performing selective electron microscopy, echography and Doppler in the appearance of signs of delayed endometrial development on the day 7 in the program of ART treatment. It is advisable for all patients in the ART treatment program to determine and evaluate the thickness of the endometrium on day 7 of the treatment cycle and, by the results of this study, to decide on the need for correction of the endometrial development, by performing an endometrial injection scratching procedure, which should be prescribed only to women with a sign of marked endometrial development delay ( $\leq 4 \mathrm{~mm}$ before the specified period). In the appointment of injection scratching to correct the delayed development of the endometrium in patients with a pronounced degree it is not advisable, given the low efficiency, to increase the daily dose of estradiol in pre-gravid preparation during HRT in the cryo-ET program.

Injection-scratching procedure in patients with severe endometrial development delay provides an adequate degree of vascularization and improves angiogenesis processes closely related to synchronization of morphological, hormonal, cytokine and immunological regulation. It eliminates resistance to HRT influence that is used to correct the inconsistency of endometrial development with the $\mathrm{MC}$ day during the treatment by ART methods. In patients with marked endometrial developmental delay, the performed injection scratching credibly improved histological and immunohistochemical criteria for endometrial developmental delay and the endometrium selective electron microscopy results.

\section{REFERENCES/ЛITEPATYPA}

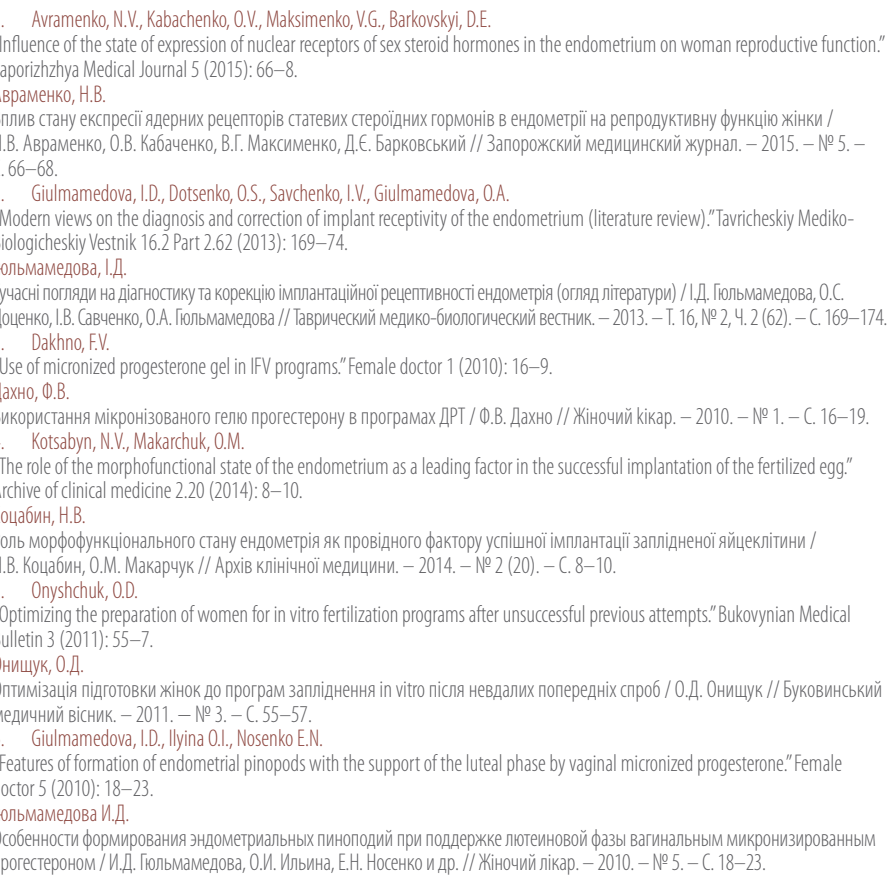


Chayka, V.K., Chayka, A.V., Nosenko, E.N. Endometrial receptivity in patients with infertility. Donetsk. Knowledge Publishing House, Donetsk Branch (2011): 243 p.

Чайка, В.К.

Рецептивность эндометрия у пациенток с бесплодием / В.К. Чайка, А.В. Чайка,

Е.Н. Носенко и др. - Донецк : Издательство Ноулидж, Донецкое отделение,

2011. $-243 \mathrm{C}$.

8. Seidova, L.A., Yavorskaya, K.A.

"Paracrine implantation regulators." Problems of reproduction 3 (2010): 7-10.

Сеидова, Л.А.

Паракринные регуляторы имплантации / Л.А. Сеидова, К.А. Яворская // Проблемы

репродукции. -2010 . - № 3. - C. 7-10.

9 Sheyderman MG

"The problem of thin endometrium: the possibility of combined non-hormonal treatment in preparation for the procedure of in vitro fertilization." Female doctor 6 (2016): 19-25. Шнейдерман, М.Г.

Проблема тонкого эндометрия: возможности комбинированного негормонального печения при подготовке к процедуре экстракорпорального опподотворения /

М.Г. Шнейдерман // Жіночий лікар. - 2016. - № 6. - С. 19-25.

10. Shurshalina, A.

"Pregravid preparation of an endometrium and auxiliary reproductive technologies." Gynecology 15.2 (2013): 12-14.

Шуршалина, А.B.

Прегравидарная подготовка эндометрия и вспомогательные репродуктивные технологии /A B. H .

11. Shcherbina, M. . Tkachova, OV Skorbach, 0.1

"Preparation of the endometrium for implantation in women of reproductive age."

Neonatology, surgery and perinatal medicine 5.3 (2015): 89-93.

Щербина, М.0.

Підготовка ендометрія до імплантації в жінок репродуктивного віку / м.0. Щербина,

0.В. Ткачова, 0.І. Скорбач // Неонатологія, хірургія та перинатальна медицина -

2015. - T.5, № 3. - C.89-93.
12. Baum, M., Yerushalmi, G.M., Maman, E., et al.

"Does local injury to the endometrium before IVF cycle

really affect treatment outcome? Results of a randomized placebo controlled trial."Gynecol Endocrinol 28 (2012):933-6.

13. Ferraretti, A.P. Goossens, V., Kupka, M., et al.

"Assisted reproductive technology in Europe, 2009: Results generated from European

registers by ESHRE." Hum Reprod 28 (2013): 2318-31.

14. Bettocchi, S., Achilarre, M.T., Ceci, O., et al.

"Fertility-enhancing hysteroscopic surgery." Seminars in Reproductive Medicine 29 (2011)

$75-82$.

15. Garcia Velasco

Auto-immunity and/or thrombophilia as causes for recurrent implantation failure: myth

or reality? Instituto Valenciano de Infertilidad, Reproductive Endocrinology and Infertility. Madrid (2012)

16. Granot, I., Gnainsky, Y., Dekel, N.

"Endometrial inflammation and effect on implantation improvement and pregnancy

outcome." Reproduction 44 (2012): 61

17. Guven, S., Kart, C. Unsal, M.A. et a.

"Endometrial injury may increase the clinical pregnancy rate in normoresponders

undergoing long agonist protocol ICSI cycles with single embryo transfer" Eur J Obstet

Gynecol Reprod Biol 173 (2014): 58-62.

18. Lensen, S., Sadler, L., Farquhar, $C$

"Endometrial scratching for subfertility: Everyone's doing it." Hum Reprod 31 (2016)

$1241-4$.

19. Li.TC

Evidence based management of the couple with recurrent implantation failure. ESHRE

(2012): $0 \rightarrow 088$.

20. Macklon, $N$.

"Laboratory: The embryo- ᄀendometrial interface - role in implantation/develoomental

success."The contribution of the endometrium University of Southampton, Academic Unit

of Human Health and Development Mailpoint. ESHRE: 29th Annual Meeting. Paramedical

invited session. - London, UK, 7-10 July 2013.
21. Nastri, C.O., Ferriani, R.A., Raine-Fenning, N., et al.

"Endometrial scratching performed in the non-transfer cycle and outcome of assisted

reproduction: a randomized controlled trial."Ultrasound Obstet Gynecol 42 (2013):

$375-82$

22. Nastri, C. O. Lensen, S.F. Gibreel, A. et al.

"Endometrial injury in women undergoing assisted reproductive techniques." Cochrane

Database Syst Rev 3 (2015): CD009517.

23. Panagiotopoulou, N., Karavolos, S., Choudhary, M.

"Endometrial injury prior to assisted reproductive techniques for recurrent implantation failure: a systematic literature review." Eur J Obstet Gynecol Reprod Biol 193 (2015):

$27-33$.

24. Singh, N. Toshyan, V., Kumar, S., et at.

"Does endometrial iniury enhances implantation in recurrent in-vitro fertilization failures? A prospective randomized control study from tertiary care center."J Hum Reprod Sci 8.4

25. Bosteels, J., Kasius, J., Weyers, S., et al.

"Treating suspected uterine cavity abnormalities by hysteroscopy to improve reproductive outcome in women with unexplained infertility or prior to IUI, IVF, or ICSI." Gynecologica Surgery 10 (2013): 165-7.

26. Vélez, M.P. Connolly. M.P. Kadoch, L, etal.

"Universal coverage of IVF pays off." Hum Reprod 29 (2014): 1313-9.

EFFECT OF ENDOMETRIAL INJECTION SCRATCHING IN CYCLES OF TREATMENT BY ASSISTED REPRODUCTIVE TECHNOLOGY METHODS

L.V. Suslikova, MD, professor, director of the Ukrainian State Institute of Reproductology, P.L. Shupik NMAPE, Kyiv

V.V. Kaminskyi, MD, professor, corresponding member of the NAMS of Ukraine, head of the Obstetrics, Gynecology and Reproductology Department, P.L. Shupyk NMAPE, head of KCCRPM, Kyiv

K.V. Chayka, MD, professor of the Obstetrics, Gynecology and Reproductology Department, P.L. Shupik NMAPE, Kyiv

A.V. Kaminskyi, MD, associate professor, head of Clinic of reproductive technology, Ukrainian State Institute of Reproductology, P.L. Shupik NMAPE, Kyiv

A.V. Serbeniuk, PhD, obstetrician-gynecologist, Clinic of reproductive technology, USIR, P.L. Shupik NMAPE, Kyiv

R.V. Zhykharskyi, PhD, head of the Department of Endometriosis and Pelvic Surgery, KCCRPM, Kyiv

O.Y. Bondaruk, graduate student, Obstetrics, Gynecology and Reproductology Department, obstetrician gynecologist, Clinics of Reproductive Technologies, USIR, P.L. Shupyk NMAPE, Kyiv

Objective: optimization of pregravid (pre-pregnancy) preparation in patients with tubal-peritoneal infertility factor and marked delay in endometrial development after unsuccessful assisted reproductive technology (ART) treatment by the use of endometrium injection scratching technology with autoplasma.

Material and methods. Study included 40 cases of unsuccessful treatment attempts for tubal-peritoneal factor infertility with severe delay of endometrial development and 10 patients with tubal-peritoneal factor infertility with normal endometrium with one or more unsuccessful ART attempts on history and the existence of cryopreserved embryos of satisfactory quality from previous cycles of assisted reproductive technology. The average age was $39.5 \pm 3.1$ years. Patients were divided into groups: I - 21 patients who underwent endometrial injection scratching and hormone replacement therapy (HRT) with a standard ( $4 / 6 \mathrm{mg}$ ) dose of estradiol; $I I-19$ patients who were prescribed HRT with a standard (4/6 mg) dose of estradiol; control - 10 patients with normal endometrium who underwent cryo-ET with standard (4/6 mg) dose of estradiol.

Clinical results were evaluated and compared in terms of pregnancy rate per embryo transfer and pregnancy loss rate in the first trimester. The correspondence of the morphofunctional structure of the endometrium was evaluated by ultrasound, cytologically, Doppler measurements, histologically, immunohistochemically and via selective electron microscopy. Endometrium was $8.9 \pm 1.1 \mathrm{~mm}$ during the period of progesterone prescription in the cryoembryo transfer cycle. All participants were transferred day 5 embryos. Results In the cryo-ET program autoplasma injection scratching in patients with marked delay of endometrial development after the first seven days of monotherapy with a starting dose of estradiol was accompanied by a significant improvement in clinica outcomes in terms of pregnancy rate (25\%) and definite decrease of early reproductive losses $(25 \%)$.

Conclusions. After pre-pregnancy preparation according to our method, it is quite sufficient to perform HRT with a standard dose of estradiol (4/6 mg/day) before starting progesterone irrespective of the endometrial development degree. Meanwhile, injection scratching is advisable to be prescribed in cases of marked delay in the endometrium development and it should be combined with physiotherapy methods.

Keywords: infertility, assisted reproductive technology methods, endometrial hypoplasia, injection endometrial scratching

ЕФЕКТИВНІСТЬ ЗАСТОСУВАННЯ МЕТОДИКИ ІН'ЕКЦІЙНОГО СКРЕТЧИНГА ЕНДОМЕТРІЯ В ЦИКЛАХ ЛІКУВАННЯ МЕТОДАМИ ДОПОМІЖНИХ РЕПРОДУКТИВНИХ ТЕХНОЛОГІЙ

Л.В. Суслікова, д. мед. н., професор, директор Українського державного інституту репродуктології НМАПО ім. П.Л. Шупика, м. Київ

В.В. Камінський, д. мед. н., професор, член-кор. НАМНУкраїни, завідувач кафедрою акушерства, гінекології та репродуктології НМАПО ім. П.Л. Шупика, КМЦРРПМ, м. Київ

К.В. Чайка, д. мед. Н., професор кафедри акушерства, гінекології та репродуктологї̈ НМАПО ім. П.Л. Шупика, м. Київ

А.В. Камінський, Д. мед. Н., доцент, завідувач Клінікою репродуктивних технологій УДІР НМАПО ім. П.Л. Шупика, м. Київ

А.В. Сербенюк, К. мед. н., лікар акушер-гінеколог Клініки репродуктивних технологій УДІР НМАПО ім. П.Л. Шупика, м. Київ

Р.В. Жихарський, к. мед. Н., завідувач відділом ендометріозуі хірургії таза КМЦРПМ, м. Київ

0.Я. Бондарук, аспірант кафедри акушерства, гінекології та репродуктології, лікар акушер-гінеколог Клініки репродуктивних технологій УдіР нмАПО ім. П.Л. Шупика, м. Київ

Мета дослідження: оптимізація прегравідарної підготовки у пацієнток із трубно-перитонеальним фактором безпліддя та вираженим відставанням розвитку ендометрія після невдалих спроб лікування методами допоміжних репродуктивних технологій (ДРТ) шляхом використання технології ін'єкційного скретчингу аутоплазмою ендометрія.

Матеріали та методи. У дослідження увійшли 40 жінок із невдалими спробами лікування методами ДРТ трубно-перитонеального фактору безпліддя з вираженим відставанням розвитку ендометрія та 10 паціенток із трубно-перитонеальним фактором безпліддя з нормальним ендометрієм, однією або кількома невдалими спробами ДРТ в анамнезі та наявністю кріоконсервованих ембріонів задовільної якості з попередніх циклів ДРТ. Середній вік жінок становив 39, 5 ะ 3,1 року. Учасниці були розподілені на групи: I - 21 пацієннтка, кожній з яких було проведено процедуру ін'єкційного скретчингу ендометрія та призначено замісну гормональну терапію (ЗГТ) зі стандартною дозою естрадіолу (4/6 мг); $I$ - - 19 пацііннток, яким було призначено 3 Т зі стандартною дозою естрадіолу (4/6 мг); контроль - 10 пацієеток із нормальним ендометрієм, яким було проведено ембріотрансфер вітріфікованих ембріонів (КРІ0-ЕТ) і призначена стандартна доза естрадіолу (4/6 мг). Клінічні результати оцінювалися за показниками частоти настання вагітності на перенос ембріонів і частоти втрат вагітності в I триместрі. Відповідність морфофункціональної структури ендометрія оцінювали шляхом УЗД, допплерометрії, гістологічно, імуногістохімічно і за допомогою селективної електронної мікроскопії. Товщина ендометрія становила 8,9 $\pm 1,1$ мм у період призначення прогестерону в циклі кріоембріотрансферу. Усім досліджуваним було перенесено ембріони п'яти днів культивування.

Результати. У програмі КРІ0-ЕТ виконання ін'єкційного скретчингу аутоплазмою в пацієнтокіз вираженим відставанням розвитку ендометрія супроводжувалося значним поліпшенням клінічних результатів за показником частоти настання вагітності (25\%) ізначним зниженням частоти ранніх репродуктивних втрат (25\%)

Висновки. Після прегравідарної підготовки за описаною методикою в програмі КРІ0-ЕТ цілком достатньо проводити ЗГТ стандартною дозоюе естрадіолу (4/6 мг/доба) до початку використання прогестерону незалежно від ступеня розвитку ендометрія. При цьому ін'єкційний скретчинг доцільно призначати у випадках вираженої затримки розвитку ендометрія та комбінувати з фізіотерапевтичними методами.

Ключові слова: безпліддя, методи допоміжних репродуктивних технологій, гіпоплазія ендометрія, ін'єкційний скретчинг ендометрія.

ЭФФЕКТИВНОСТЬ ИСПОЛЬЗОВАНИЯ МЕТОДИКИ ИНЪЕКЦИОННОГО СКРЕТЧИНГА ЭНДОМЕТРИЯ В ЦИКЛАХЛЕЧЕНИЯ МЕТОДАМИ ВСПОМОГАТЕЛЬНЫХ РЕПРОДУКТИВНЫХ ТЕХНОЛОГИЙ

Л.В. Сусликова, Д. мед. Н., профессор, директор Украинского государственного института репродуктологии НМАПО им. П.Л. Шупика, г. Киев

В.В. Каминский, Д. мед. Н., профессор, член-корр. НАМН Украины, заведующий кафедрой акушерства, гинекологии и репродуктологии НМАПО им. П.Л. Шупика, КГЦРПМ, г. Киев

К.В. Чайка, А. мед. Н., профессор кафедры акушерства, гинекологии и репродуктологии НМАПО им. П.Л. Шупика, г. Киев

А.В. Каминский, д. мед. Н., доцент, заведующий клиникой репродуктивных технологий УГИР НМАПО им. П.Л. Шупика, г. Киев

АВ. Сербенюк К.

Р.В. Жихарский, к. мел. н. заведующий отделом эндометриоза и хирургии таза КГЦРПМ, г. Киев

0.Я. Бондарук, аспирант кафедры акушерства, гинекологии и репродуктологии, врач акушер-гинеколог Клиники репродуктивных технологий УгИР нМАПО им. П.Л. Шупика, г. Киев

Цель исследования: оптимизация прегравидарной подготовки у пациенток с трубно-перитонеальным фактором бесплодия и выраженным отставанием развития эндометрия после неудачных попыток лечения методами вспомогательных

репродуктивных технологий (ВРТ) путем использования технологии инъекционного скретчинга аутоплазмойэндометрия.

Материалы и методы. Висследование вошли 40 женщин с неудачными попытками лечения методами ВРТ трубно-перитонеального фактора бесплодия с выраженным отставанием развития эндометрия и 10 пациенток с трубно-перитонеальным фактором бесплодия с нормальным эндометрием, одной или несколькими неудачными попытками ВРТ в анамнезе и наличием криоконсервированных эмбрионов удовпетворительного качества из предыдущих цикпов ВРТ Средний возраст женщин составил $39,5 \pm 3,1$ года. Участницы были распределены на группы: I - 21 пациентка, каждой из которых была проведена процедура инъекционного скретчинга эндометрия и назначена заместительная гормональная терапия (ЗГТ) со стандартной дозой эстрадиола (4/6 мг), II - 19 пациенток, которым была назначена ЗГТ со стандартной дозой эстрадиола (4/6 мг), контроль - 10 пациенток с нормальным эндометрием, которым был проведен эмбриотрансфер витрифицированных эмбрионов (КРИО-ЭТ) и назначена стандартная доза эстрадиола (4/6 мг).

Клинические результаты оценивались по показателям частоты наступления беременности на перенос эмбрионов и частоты потерь беременности в I триместре. Соответствие морфофункциональной структуры эндометрия оценивали путем Узи, допплерометрии, гистологически, иммуногистохимически и с помощью селективной электронной микроскопии. Толщина эндометрия составила 8,9 1 1,1 мм в период назначения прогестерона в цикле криоэмбриотрансфера. Всем участницам исследования были перенесены эмбрионы пяти дней культивирования.

Результаты. В программе КРИО-ЭТ выполнение инъекционного скретчинга аутоплазмой у пациенток с выраженным отставанием развития эндометрия сопровождалось значительным улучшением клинических результатов по показателю частоты наступления беременности (25\%) и значительным снижением частоты ранних репродуктивных потерь (25\%).

Выводы. После прегравидарной подготовки по описанной методике в программе КРИО-ЭТ вполне достаточно проводить ЗГТ стандартной дозойэстрадиола (4/6 мг/сутки) до начала использования прогестерона независимо от степени развития эндометрия. При этом инъекционный скретчинг целесообразно назначать в случаях выраженной задержки развития эндометрия и комбинировать с физиотерапевтическими методами. 